Journal of Fundamental and Applied Sciences

ISSN 1112-9867

Available online at

http://www.jfas.info

\title{
SEASONAL VARIATIONS IN GROUNDWATER QUALITY OF VALSAD DISTRICT OF SOUTH GUJARAT (INDIA)
}

\author{
P. Shroff and R. T.Vashi* \\ Department of Chemistry, Navyug Science College, Rander Road,Surat,India
}

Received: 28 January 2015 / Accepted: 04 February 2015 / Published online: 05 February 2015

\begin{abstract}
Groundwater is an important precious natural resource. For optimum utilization of water resources, it is necessary to know both the quality as well as quantity of water. The present investigation is focused on seasonal variation in groundwater quality of Valsad district of south Gujarat (India). Groundwater samples from fifteen sampling stations were collected for two year i.e. from Aug 2007 to July 2009 and analyzed for pH, Colour, Total Hardness (TH), Calcium (Ca), Magnesium (Mg), Total Alkalinity (TA), Chloride and Sodium. Marginally higher level was observed in almost all parameters in summer season. No significant change observed in $\mathrm{pH}$, Colour and Calcium.
\end{abstract}

Keys Words: Ground Water, Seasonal Variations, Valsad District, Gujarat.

\section{INTRODUCTION}

Groundwater is a crucial source of fresh water through out the world. It is an important natural resource that has to be conserved and preserved for sustenance of life in future [1].

Groundwater was considered to be very clean and safe in past but nowadays it is getting polluted with rapid growth of urban and industrial activities, particularly in the developing countries, where proper waste disposal measures are not followed.

Determination of physico-chemical characteristics of water is essential for assessing the suitability of water for various purposes like drinking, domestic, industrial and agriculture. The groundwater quality may also vary with seasonal changes [2].

Author Correspondence, e-mail: vashirajendra@yahoo.co.in ICID: 1138788 
Water quality assessment generally involves analysis of physicochemical, biological and microbiological parameters and reflects on abiotic and biotic status of the ecosystem. This, in turn, helps in planning exploitation, antipollution or conservation strategies. Further, due to their open nature and constant change of matter and energy goes on between ecosystem and its surroundings thus making water quality a dynamic entity. The present paper assesses the groundwater quality in some villages of Valsad district and studies the effect of seasonal variations on the groundwater quality.

\section{MATERIALS AND METHODS}

Valsad district is laid between $20^{\circ} 8^{\prime}$ to $21^{0} 9^{\prime} \mathrm{N}$ latitudes, and $62^{0} 39^{\prime}$ to $73^{0} 30^{\prime} \mathrm{E}$ longitudes. The district has $74.10 \mathrm{~km}$ long sea belt. Average rainfall in this region is 1500 to $2200 \mathrm{~mm}$. The district has four main rivers named Auranga, Par, Damanganga and kolak. Total fifteen sampling stations are selected for study of groundwater of Valsad district. Details of sampling station is given in Table 1 .

Table 1: Sampling stations, locations and type of ground water sources

\begin{tabular}{|l|l|l|}
\hline Sampling Station & Location & Type of groundwater source \\
\hline S1 & Tithal & Bore well \\
\hline S2 & Dhamdachi & Bore well \\
\hline S3 & Haria & Hand pump \\
\hline S4 & Pardi & Hand pump \\
\hline S5 & Khadki & Hand pump \\
\hline S6 & Vapi & Bore well \\
\hline S7 & Valvada & Hand pump \\
\hline S8 & Bhilad & Hand pump \\
\hline S9 & Sarigam & Well \\
\hline S10 & Nanapondha & Bore well \\
\hline S11 & Kaprada & Well \\
\hline S12 & Sutharpada & Hand pump \\
\hline S13 & Dharmpur & Bore well \\
\hline S14 & Barumal & Hand pump \\
\hline S15 & Kakadkua & Hand pump \\
\hline
\end{tabular}


The climate of the Valsad district is neither hotter nor cooler, it is temperate. It has three distinct seasons viz., Winter - from middle of October to February, Summer - from March to middle of June and Monsoon - from middle of June to middle of October.

The groundwater samples were collected in two litre polythene bottles which were thoroughly washed twice with the water to be analyzed. The physico-chemical parameters like $\mathrm{pH}$, Colour, Total hardness (TH), Calcium (Ca), Magnesium (Mg), Total Alkalinity (TA), Chloride and Sodium were estimated as per APHA [3].

\section{RESULTS AND DISCUSSION}

Seasonal variation among parameters of groundwater samples of Valsad district are presented in fig. 1 and 2. It should be noted that precipitation as rainfall over Valsad district has been highly variable over the past several years. This together with the local weather conditions dominated by the high temperatures, dry climate and unpredictable monsoon pattern, makes it difficult to conclusively quantity the water quality as could be otherwise found in a normal monsoon year.

Also, the results of water quality might be highly influenced by such drastic weather conditions and hence mask the effect of any other factor affecting the water quality of this region [4].

A $\mathrm{pH}$ value of water is an important index of acidity, alkalinity and resulting value of the acidic-basic interaction of a number of its mineral and organic components [5]. A pH level of three seasons were shown in decreasing order: winter (7.4) > summer (7.3) > monsoon (7.3). Seasonwise distribution of data indicates no significant change in $\mathrm{pH}$ value.

Colour level of three seasons were shown in decreasing order: summer (4 hazen) $>$ winter (3 hazen) $>$ monsoon (3 hazen). Seasonwise distribution of data indicates no significant change in colour value.

TH level of three seasons were shown in decreasing order: summer $(377 \mathrm{mg} / \mathrm{l})>$ winter $(364$ $\mathrm{mg} / \mathrm{l})>$ monsoon $(363 \mathrm{mg} / \mathrm{l})$. Seasonwise distribution of data indicates little higher values in TH in summer.

Ca level of three seasons were shown in decreasing order: summer $(89 \mathrm{mg} / \mathrm{l})>$ winter $(88$ $\mathrm{mg} / \mathrm{l})>$ monsoon $(88 \mathrm{mg} / \mathrm{l})$. Seasonwise distribution of data indicates no significant change in $\mathrm{Ca}$ in summer.

Mg level of three seasons were shown in decreasing order: summer $(38 \mathrm{mg} / \mathrm{l})>$ winter $(35$ $\mathrm{mg} / \mathrm{l})>$ monsoon $(35 \mathrm{mg} / \mathrm{l})$. Seasonwise distribution of data indicates little higher values in $\mathrm{Mg}$ in summer. 
TA level of three seasons were shown in decreasing order: summer $(272 \mathrm{mg} / \mathrm{l})>$ winter $(265$ $\mathrm{mg} / \mathrm{l})>$ monsoon $(258 \mathrm{mg} / \mathrm{l})$. Seasonwise distribution of data indicates little higher values in TA in summer. In the main land scenario, the groundwater quality in terms of salinity and hardness is generally better during monsoon and gets deteriorated in summer or pre-monsoon [6]. Total alkalinity was high during summer and low during rainy season on account of dilution of water. A similar opinion has been expressed by Jain et al. [7,8].

Chloride level of three seasons were shown in decreasing order: summer $(186 \mathrm{mg} / \mathrm{l})>$ monsoon $(183 \mathrm{mg} / \mathrm{l})>$ winter $(181 \mathrm{mg} / \mathrm{l})$. Seasonwise distribution of data indicates little higher values in chloride in summer. The higher value during summer may be due to evaporation of water and mixing of organic waste of animal origin [7].

Sodium level of three seasons were shown in decreasing order: summer $(129 \mathrm{mg} / \mathrm{l})>$ winter $(125 \mathrm{mg} / \mathrm{l})>$ monsoon $(122 \mathrm{mg} / \mathrm{l})$. Seasonwise distribution of data indicates little higher values in summer.

SAR level of three seasons were shown in decreasing order: summer (2.62) > winter (2.51)> monsoon (2.42). Seasonwise distribution of data indicates little higher values in SAR in summer.

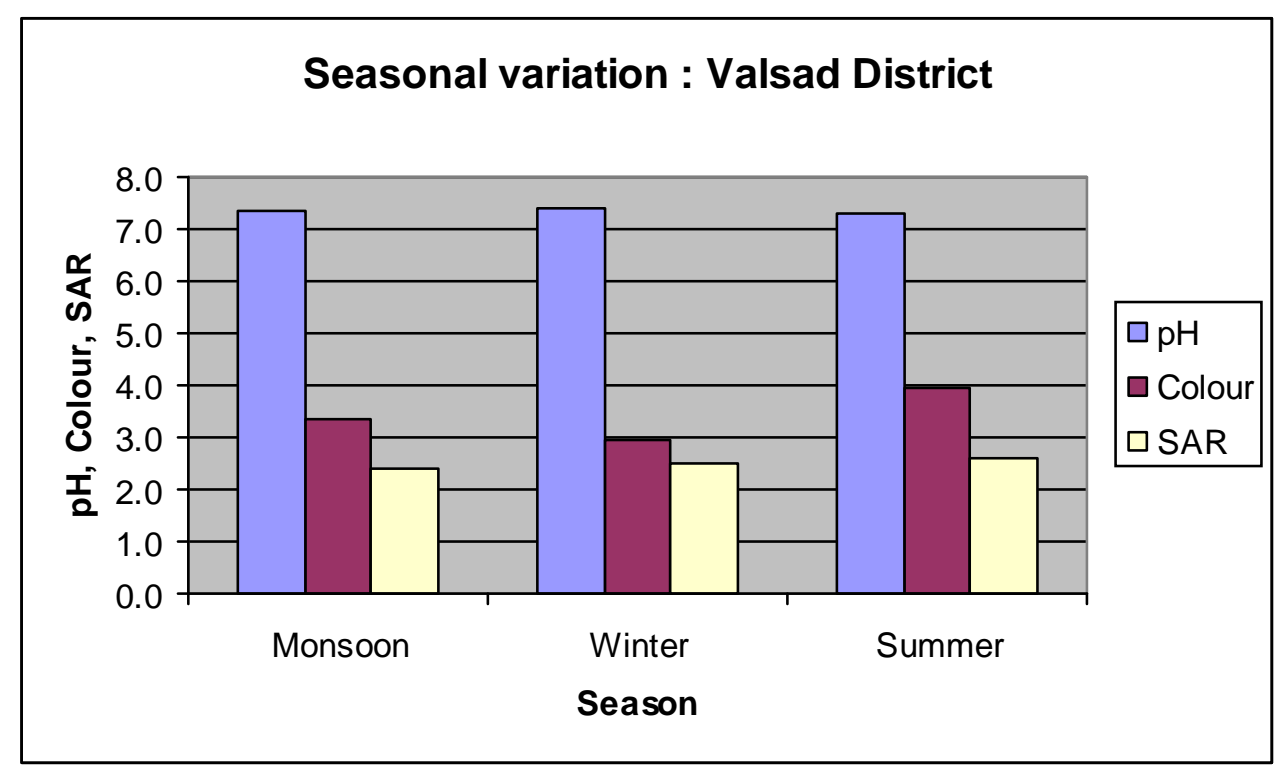

Fig. 1. Seasonal variation in Valsad district for $\mathrm{pH}$, Colour, SAR 


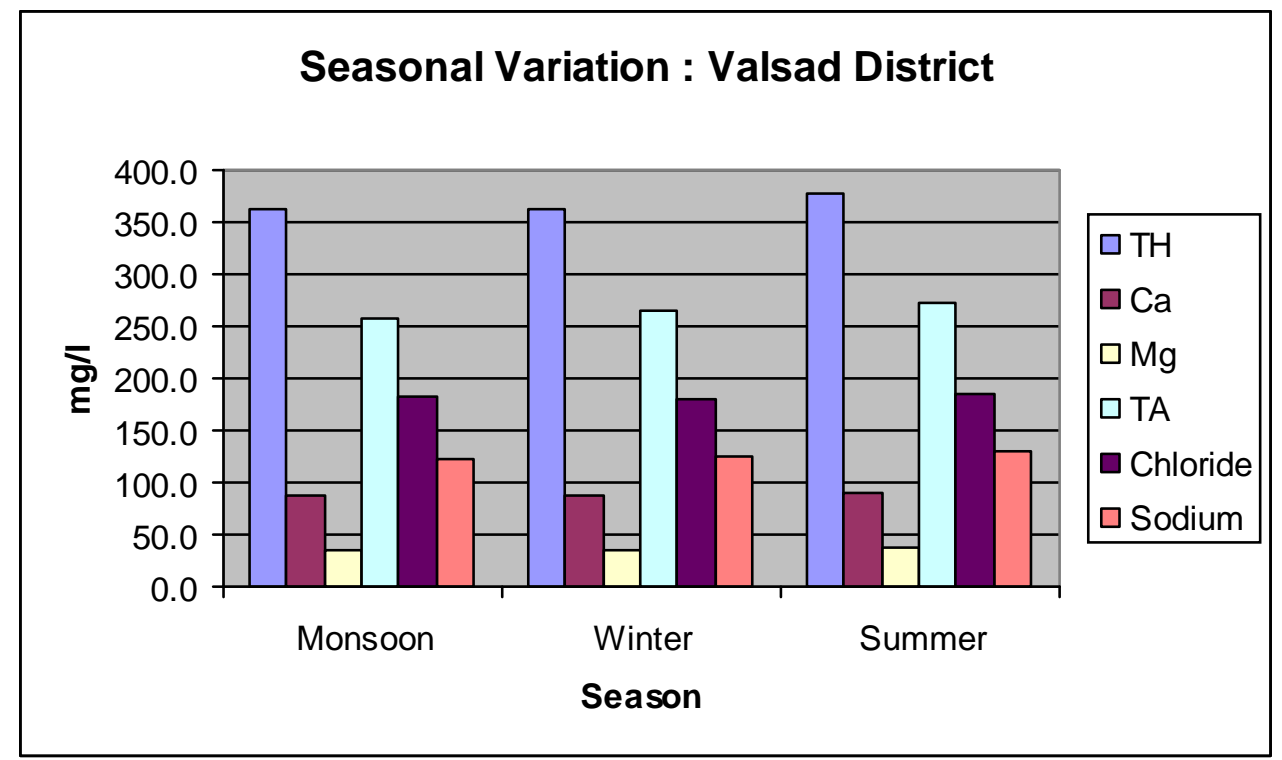

Fig. 2. Seasonal variation in Valsad district for $\mathrm{TH}, \mathrm{Ca}, \mathrm{Mg}, \mathrm{TA}$, Chloride, Sodium.

\section{CONCLUSIONS}

It can be observed that the groundwater quality in Valsad district as reflected by the physicochemical characteristics of groundwater samples from selected sampling stations varies widely. On the basis of above discussion, it may be concluded that majority of parameters are marginally higher in summer season.

\section{ACKNOWLEDGEMENTS}

The authors are grateful to Department of chemistry, Navyug Science College, Surat for providing the laboratory facility required to carry out the present work.

\section{REFERENCES}

[1] Mheshwaran G.and Elangovan K., J. Envi. Sci.and Engg., 2010, 52(1), 47-52.

[2] LeninSunder M. and Saseetharan M. K., J. Envi. Sci.and Engg., 2008, 50(3), 187-190.

[3] Patel S. R., Physico-chemical and microbiological characterization of potable waters used in villages of Surat district, Thesis submitted to Veer Narmad South Gujarat University 2005.

[4] American Public Health Association, Standard Methods for the Examination of Water and Wastewater, 20th edition, Washington D.C., 1998.

[5] Anamika, Asian J. Chem., 2008, 20(6), 4659-4663.

[6] Narasimha Prasad N. B. and Mansoor O. A., J. Envi. Sci. and Engg., 2005,47(4) ,69-74. 
[7] Chaudhary P., Dhakad N. K. and Parveen S., J. Env. Res. and Develop. , 2006, 1(2).

[8] Jain S. M., Sharma M. and Thakur R., Indian Ecobiol., 1996, 8(3),181-188.

\section{How to cite this article}

Shroff P, Vashi T. Seasonal variations in groundwater quality of valsad district of south Gujarat (INDIA). J Fundam Appl Sci. 2015, 7(2), 163-168. 